\title{
"Regulatory assessment of the bank market risk: international approaches and Ukrainian practice"
}

\begin{tabular}{|c|c|}
\hline \multirow{8}{*}{ AUTHORS } & Yana Kuznichenko iD https://orcid.org/0000-0003-0815-4939 \\
\hline & R http://www.researcherid.com/rid//-8869-2018 \\
\hline & Serhiy Frolov iD https://orcid.org/0000-0001-9374-7274 \\
\hline & R http://www.researcherid.com/rid/C-1635-2018 \\
\hline & Fedir Zhuravka iD https://orcid.org/0000-0001-8368-5743 \\
\hline & R http://www.researcherid.com/rid/P-4821-2014 \\
\hline & Mykola Yefimov iD https://orcid.org/0000-0003-3964-798X \\
\hline & Volodymyr Fedchenko id https://orcid.org/0000-0003-4006-3535 \\
\hline ARTICLE INFO & $\begin{array}{l}\text { Yana Kuznichenko, Serhiy Frolov, Fedir Zhuravka, Mykola Yefimov and } \\
\text { Volodymyr Fedchenko (2018). Regulatory assessment of the bank market risk: } \\
\text { international approaches and Ukrainian practice. Banks and Bank Systems, } \\
\text { 13(4), 73-84. doi:10.21511/bbs.13(4).2018.07 }\end{array}$ \\
\hline DOI & http://dx.doi.org/10.21511/bbs.13(4).2018.07 \\
\hline RELEASED ON & Friday, 07 December 2018 \\
\hline RECEIVED ON & Tuesday, 30 October 2018 \\
\hline ACCEPTED ON & Wednesday, 05 December 2018 \\
\hline & $(\mathrm{cc})$ EY \\
\hline LICENSE & $\begin{array}{l}\text { This work is licensed under a Creative Commons Attribution } 4.0 \text { International } \\
\text { License }\end{array}$ \\
\hline JOURNAL & "Banks and Bank Systems" \\
\hline ISSN PRINT & $1816-7403$ \\
\hline ISSN ONLINE & $1991-7074$ \\
\hline PUBLISHER & LLC "Consulting Publishing Company "Business Perspectives" \\
\hline FOUNDER & LLC “Consulting Publishing Company "Business Perspectives" \\
\hline & $\begin{array}{l}\text { ZE: } \\
\text { =-E }\end{array}$ \\
\hline NUMBER OF REFERENCES & NUMBER OF FIGURES \\
\hline 27 & 2 \\
\hline
\end{tabular}

(C) The author(s) 2023. This publication is an open access article. 


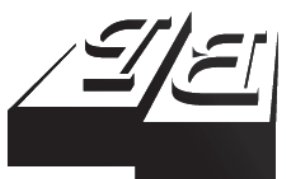

BUSINESS PERSPECTIVES

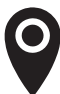

LLC "CPC "Business Perspectives" Hryhorii Skovoroda lane, 10, Sumy, 40022, Ukraine

www.businessperspectives.org

Received on: $30^{\text {th }}$ of October, 2018 Accepted on: $5^{\text {th }}$ of December, 2018

(C) Yana Kuznichenko, Serhiy Frolov, Fedir Zhuravka, Mykola Yefimov, Volodymyr Fedchenko, 2018

Yana Kuznichenko, Chief Expert of the Methodology Department, National Bank of Ukraine, Ukraine.

Serhiy Frolov, Doctor of Economics, University of Customs and Finance, Dnipro, Ukraine.

Fedir Zhuravka, Doctor of Economics, Professor, Sumy State University, Ukraine.

Mykola Yefimov, Ph.D. in Law, Senior Lecturer, State University of Internal Affairs, Dnipro, Ukraine.

Volodymyr Fedchenko, Ph.D. in Law, Professor, State University of Internal Affairs, Dnipro, Ukraine.

\section{() (i)}

This is an Open Access article, distributed under the terms of the Creative Commons Attribution 4.0 International license, which permits unrestricted re-use, distribution, and reproduction in any medium, provided the original work is properly cited.
Yana Kuznichenko (Ukraine), Serhiy Frolov (Ukraine), Fedir Zhuravka (Ukraine), Mykola Yefimov (Ukraine), Volodymyr Fedchenko (Ukraine)

\section{REGULATORY ASSESSMENT OF THE BANK MARKET RISK: INTERNATIONAL APPROACHES AND UKRAINIAN PRACTICE}

\begin{abstract}
The implementation of international standards for the bank risk assessment and market risk in particular, in Ukrainian banking practice is aimed at achieving common standards for regulating banking activities in different countries. This should help to increase the banking sector stability in Ukraine and, accordingly, increase the interest of foreign investors.

The article deals with the methodological approaches to assessing the bank market risk (in particular, SA, IMA and R-SbM approaches) recommended by the Basel Committee on Banking Supervision in terms of standardization and unification of the normative framework of capital requirements for Ukrainian banks. Considering the analysis results, it was determined that the choice and implementation of an optimal approach in the context of Ukrainian banking practice can be carried out in one of two alternative scenarios: 1) a simplified version of a sensitivity based method (R-SbM); and 2) a recalibrated version of the Basel II standardized approach. In this case, the Basel II recalibrated version is more acceptable for use by banks, since it is most relevant to volume and complexity of transactions carried out by Ukrainian banks.

The obtained results are aimed at improving the existing methodology for calculating the adequacy ratio of banks' regulatory capital (N2), which currently considers only the needs for credit risk coverage, and at refining the methodology in terms of considering banks' market-risk coverage needs.
\end{abstract}

\section{Keywords}

banking institution, assessment, methodology, market risk, requirements, Basel Committee on Banking Supervision

JEL Classification G20, G21

\section{INTRODUCTION}

Dynamic development and transformation of the modern market environment lead to a significant increase of competition in the domestic and foreign markets. This, in turn, results in both new and modified factors affecting the development and efficiency of banking activities. This is naturally accompanied by actualization of increasing the efficiency of banking risks management. Market risk is one of them. According to the Core Principles for Effective Banking Supervision by the Basel Committee on Banking Supervision (BCBS), market risk is one of mandatory elements of the bank's risk management system. Among other risks, it should be subject to monitoring by the relevant supervisory authority, which should develop minimum standards for overseeing the adequate use of banking management and control systems as a basis for calculating capital.

Integrating the Ukrainian banking system into the global financial space in the context of complicating bank transactions and expanding 
the range of risks create a strong demand for quality risk management. At the same time, implementation of risk-oriented instruments deserves attention, which would allow banks to identify, adequately assess and effectively manage these risks, analyze the stability of banks based on a balanced combination of international approaches and peculiarities of accounting and prudential supervision of the National Bank of Ukraine.

The purpose of the article is to analyze international approaches to assessing market risk of a bank in order to improve the methodology for calculating the regulatory capital adequacy in Ukrainian banks.

\section{THEORETICAL BASIS}

Increased attention of the world banking community to market risk as a potential source of significant losses was a consequence of the sharp increase in the volumes of trade transactions carried out by banks in the early 1980s. Risk management systems existing at that time were not able to control the price risks of possible losses due to changes in the price of a commodity or financial instrument in time that is inherent in trading activity, as well as the level of capital acceptable to absorb such risks.

A full-fledged activity aimed at developing standards for market risk assessment and its incorporation, as an integral part, in calculating the capital adequacy ratio began with the introduction of the BCBS (whose principles have a comprehensive international status and are aimed at strengthening the regulatory regime in all jurisdictions) Consultative document "International Convergence of Capital Measurement and Capital Standards" (Basel I).

Many scholars investigated the issue of definition and substantiation of the essence of market risk of a bank, its detection, evaluation, management and control.

The Basel Committee on Banking Supervision defines market risk as the risk of losses in on- or off-balance sheet items that arise from movement in market prices (Basel Committee on Banking Supervision, 2005).

Market risk refers to the risk of losses in the bank's trading book due to changes in equity prices, interest rates, credit spreads, foreign-exchange rates, commodity prices, and other indicators whose values are set in a public market (McKinsey\&Company, 2012, May).
The National Bank of Ukraine defines market risk as an existing or potential risk for revenues and capital arising from adverse fluctuations in the value of securities, commodities and foreign exchange rates on those instruments that are in the trading portfolio. This risk derives from market-making, dealing, taking positions from debt and equity securities, currencies, commodities and derivatives. Market risk includes, but is not limited to, types of risks such as default risk, interest rate risk, credit spread risk, as well as equity, commodity, and currency risk (NBU, n.d.).

In scientific works, the theoretical approaches to the understanding of the essence, features of identification and some aspects of management are highlighted. However, the issue of its evaluation remains underexplored.

Chornous and Ursulenko (2013) studied the problems of improving the bank risks assessment and management, considering the new regulatory and technological requirements based on the use of modern technology and combining the latest achievements in artificial intelligence, numerical mathematics, statistics and information technology. They proposed new approaches to assessment, based on the modern methods of data analysis. They concluded that Ukrainian banks have a lot of problems in using new approaches to risk assessment and its information support.

Mirković, Dašić, and Siljković (2013) noted that bank market risks, as well as methodologies of its quantifying and assessing (Value-at-Risk and stress testing) have the largest and almost irreplaceable role in bank systems.

Trenca (2009) investigated the VAR method in bank market risks assessment and management. 
Milanova (2010) concluded that Value at Risk (VaR) model should be used as a basic method for market risk analysis and assessment. Also, special emphasis is placed on stress tests as a technique for reliable risk management used in the potential impact assessment of individual factors or changes in many financial parameters of the bank's income, capital and economic value.

Muriithi, Muturi, and Waweru (2016) investigated the impact of market risk on financial performance of commercial banks in Kenya using balance sheets and financial ratios of 43 Kenyan commercial banks.

Mohd Fahmee Ab-Hamid et al. (2018) studied the influence of market risks on the efficiency of the Malaysian banking industry. Also, the effects of cost and profit efficiencies on post-merger bank market risk were assessed.

Kyung-Chun Mun (2018) investigated the efficiency for futures and forward hedging strategies that can be employed by large US banking firms with exposure to interest rate and foreign exchange risks.

Practical aspects of market risk assessment are a complex task for banks, as they are constantly faced with the risk of losses due to balance sheet and off-balance sheet items resulting from unfavorable fluctuations of market prices.

According to the new international approaches (Basel 2.5 and Basel 3), current standards on minimum capital requirements for banks to cover market risks have been revised and significantly improved. The review, in particular, deals with the following key areas:

- the need for a clear division of trading and bank books in order to discourage arbitrage transactions by banks due to regulatory differences in different jurisdictions;

- revision of the standardized approach to increase risk sensitivity while maintaining the complexity of market risk assessment standards for banks with moderate complexity of transactions that do not require using internal models' approach; review of the of internal models' approach by strengthening the conditions of its approval by the supervisory body; requirements for identifying material (tangible) risk factors among banks and calculating their quantitative impact on capital; introduction of additional restrictions in order to reduce the negative impact of hedging and diversification on capital;

replacing the Value-at-Risk (VaR) approach with the estimation of the Expected Shortfall (ES) exceeding VaR in order to reach the estimate in periods of significant financial stress on residual risk (tail risk is the risk of investing, the occurrence of which is unlikely. However, if used, they result in serious losses);

- completing the calculation methodology by assessing the adequacy/inadequacy of liquidity in the market. In order to mitigate the risk of unpredictable/significant deterioration of market liquidity for both approaches (the standardized approach and the domestic model's approach), a multivariate liquidity horizon is proposed instead of the static 10day horizon used for VaR.

\section{RESULTS}

A detailed analysis of the new international approaches to market risk assessment allowed to identify areas for improvement of the current methodology for calculating the adequacy ratio of banks' regulatory capital (N2) (National Bank of Ukraine, n.d.). The methodology currently considers only the needs of banks for covering credit risk. Therefore, it should be revised according to international practice in terms of considering the needs for market risk coverage by banks.

So, let us consider these approaches.

\subsection{Standardized Approach (SA) to the market risk assessment}

According to this approach, the requirement for capital adequacy for market risk is the sum of three components: 
1) risk-claims calculated using the Sensitivity- 4) commodity risk; based Method (SbM);

2) default risk (DRC) requirements; and

3) residual risk (RRAO)).

The sensitivity-based method ( $\mathrm{SbM})$ is based on the use of the following components:

1) Delta (linear risk) is a component of the bank's trading book and is used as inputs to regulate delta risk factors.

2) Vega (linear risk) is a component that, like the delta, is used as inputs to regulate the vega risk factors.

3) Curvature (nonlinear risk) is a component including additional risk, not dealt with delta risk of price change in option cost or similar financial instruments with non-linear non-payment behavior, such as collateralized securities, that is, for financial instruments whose value changes nonlinearly in relation to the basis risk factors.

Capital requirements for covering the curvature risk are calculated by estimating the maximum losses for the two stress scenarios (ascending and descending shocks) for this risk factor. The worst value under the two scenarios is a risk position and it is used as input for calculation.

All three components must be designed for each of the risks defined under the sensitivity-based method (SbM) in order to avoid rising/decreasing correlations during financial stress periods:

1) general interest rate risk (GIRR);

2) credit spread risk (CSR):

- non-securitized asset risk (non-securitization);

- risk of non-securitized assets that have no correlation with trading portfolio;

- risk of securitized assets correlating with trading portfolio;

3) equity risk;

5) foreign exchange (FX) risk.

Each of the scenarios for delta risk, vega risk and curvature risk is developed by the bank based on current financial instrument prices or the pricing models applied by the independent risk management unit. These models are used for reporting on market risks or actual gains and losses to senior executives.

The SbM method is based on the elements of the previous version of SA to market risk assessment (Milanova, 2010), when risk sensitivity was used to calculate its individual components: for example, the duration method for interest risk, the delta plus method for some financial instruments.

At the same time, the SbM method more widely uses sensitivity in the revised standardized approach and identifies market-sensitive limits that can be equally applied by different banks in different jurisdictions.

Default risk (DRC) calculates the probability of bank counterparts' default according to three types of bank assets:

1) unsecuritized assets;

2) securitized assets that do not correlate with the trading portfolio;

3) securitized assets correlating with the trading portfolio.

The calculation is a calibrated approach to determining the default risk of debtors for the credit risk of a bank book. Its aims at reducing the potential non-compliance in capital requirements for similar exposures of the bank under the risk in a trading book and in a bank book.

The default risk, like the sensitivity-based method, allows recognition of hedging, on a limited basis though.

Residual risk (RRAO) is calculated to determine the adequacy of covering all other risks not covered by the SbM and DRC methods, as well as to pro- 
tect bank's capital from the impact of complex/too complex financial instruments in its trading book.

The BCBS does not describe in detail such instruments in order not to create incentives for regulatory arbitrage and not to encourage banks to assume excessive risks due to such instruments.

In addition, while revising the SA approach and identifying certain areas where the complexity of measuring risk factors to calculate the level of losses and their aggregation are not consistent with the actual amount of risk, the BCBS has amended certain elements of the market risk calculation methodology according to this approach. The changes relate to:

- simplifying the procedure for calculating currency risk for currency pairs that are liquid and, consequently, the risk for which is lower;

- reducing correlation scenarios by eliminating those with "low" correlation;

- capital requirements for financial instruments with nonlinear risk.

In addition, weighted risk ratios for certain classes of assets are reduced to ensure the correspondence of capital requirements with the revised standardized approach.
Schematically, the general structure of capital requirements according to the revised standardized approach is as follows (see Figure 1).

\subsection{Internal Models Approach (IMA) to the market risk assessment}

According to this approach, the capital adequacy requirements are also a set of three components:

1) expected shortfall (ES);

2) default risk (DRC);

3) stressed capital add-on (SES).

In order to stimulate the effective implementation of this approach by banks, the Basel Committee on Banking Supervision proposes the following three measures:

1. It is proposed to strengthen the requirements in order to obtain the regulator's consent to use models, in particular, to establish criteria of profits and losses attribution (PLA).

The BCBS introduces a PLA test in order to carry out an unbiased and qualitative assessment of the bank's internal models used to calculate capital requirements to cover market risk, to properly measure all material risks for each type of transactions (financial instruments) of the trading book, for

\section{STANDARDIZED APPROACH (SA) TO THE MARKET RISK ASSESSMENT}

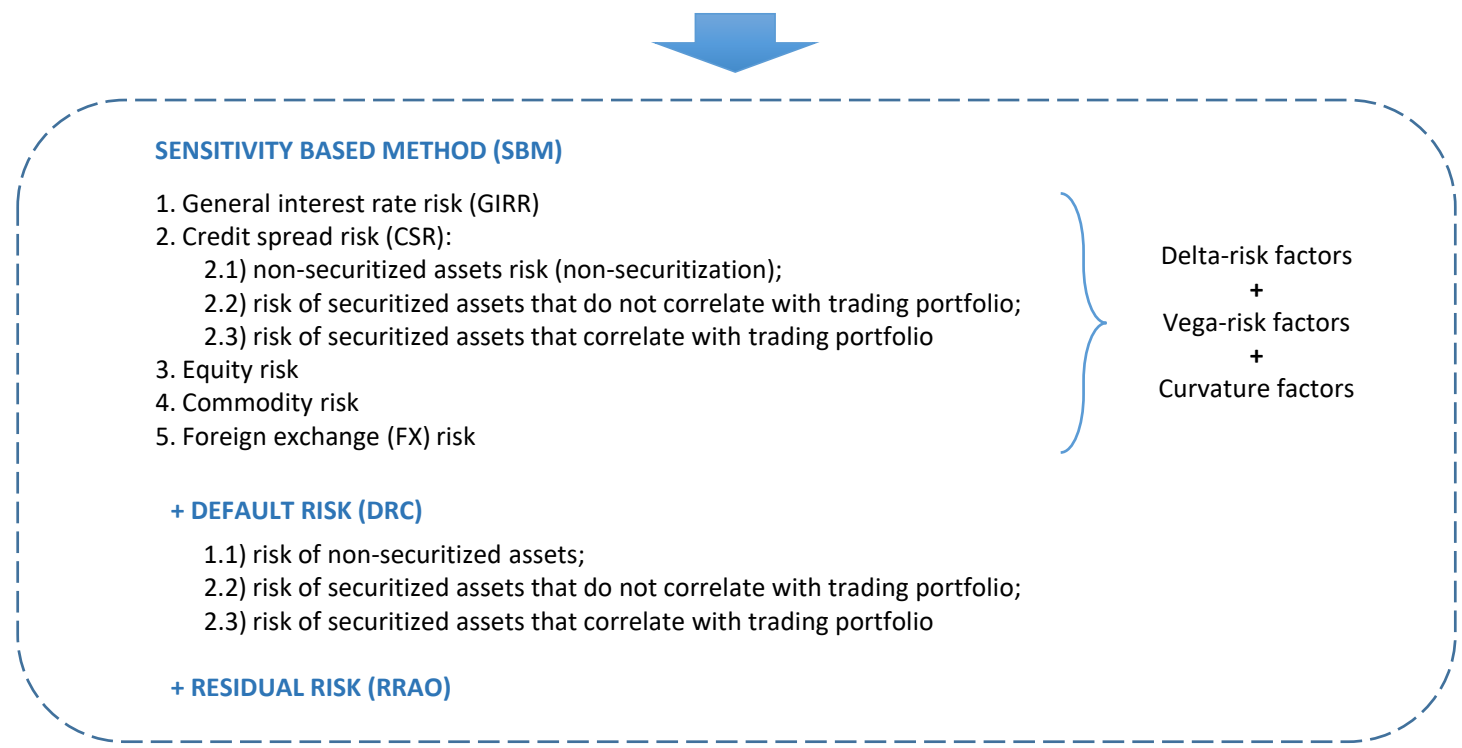

Figure 1. General structure of capital requirements according to the standardized approach 
which they are used (McKinsey\&Company, 2012, May). The test compares historic time cycles for two dimensions of daily profit and loss (P\&L) data broken down by types of transactions (financial instruments) of a trading book:

- hypothetical P\&L (HPL) are the daily P\&L calculated, excluding commissions, fees, intraday trading, and certain valuation adjustments;

- theoretical P\&L risk (RTPL) means profits and losses, adjusted only for the risk factors of the internal risk management model of a bank and the valuation methods used by the bank in this model.

With this test, the regulator evaluates the feasibility of using the models by the bank. If the test is not taken, the bank is required to apply a standardized approach.

2. More consistent and integrated risk measurement methods are recommended, including the introduction of clear capital requirements for non-modellable risk factors (NMRFs).

In particular, it is allowed to include a risk factor in the model in the presence of at least 24 "real price observations" for the last 12 months and in the absence of gaps for more than 1 month between any two observations. Such acceptability criteria are used to determine the risk factors subject to modeling. If the risk factor does not meet these criteria, it is classified as non-modellable, is excluded from the Expected Shortfall (ES) model and is considered under stressed capital add-on (SES).

3. A number of recommendations were made as to how banks should inform about changes in the minimum capital requirements to market risks according to the approaches they use to calibrate their own internal models in order to develop data aggregation mechanisms aimed at improving the availability of "real price observations " at the same time preserving their confidentiality.

Assessment of capital requirements by banks to cover market risk using the Internal Models Approach (IMA) for its approval by the supervisor should be constructed as in Figure 2.
Using the IMA by banks allows for applying their own models for quantifying market risk, built on compliance with the recommended quantitative and qualitative BCBS criteria, and can only be applied after the supervisor has given the appropriate consent. Minimum requirements for granting such consent compared to the previous IMA version have not changed. They are as follows:

conceptual perfection and integrity of the market risk management system of a bank;

- $\quad$ sufficient qualified personnel to use complex models for controlling market risks, audit and, if necessary, assisting fields;

- the ability of its own banking model to demonstrate the proper accuracy of market risk assessment;

- regular stress testing by the bank and confirming the results of stress testing by the supervisor in the following areas: a) control scenarios that do not require bank modeling; b) scenarios requiring bank modeling; c) scenarios developed by banks for specific characteristics of their portfolios;

- successful testing of the effective use of their own models in terms of types of trading portfolio operations, which they are applied to, and available positions in the bank (balance sheet and off-balance sheet items).

It follows from the above that an important prerequisite for implementing both the standardized approach and the IMA is the fact that banks make a clear distinction between their balance sheet and off-balance sheet transactions, based on their affiliation with the trading book or the bank book. And it is expedient to do this taking into account the BCBS's recommendations and criteria.

\subsection{Criteria for assigning financial instruments to the trading book}

The definition of trading and bank books contained in the regulatory acts of the National Bank of 


\section{INTERNAL MODELS APPROACH (IMA) TO THE MARKET RISK ASSESSMENT}

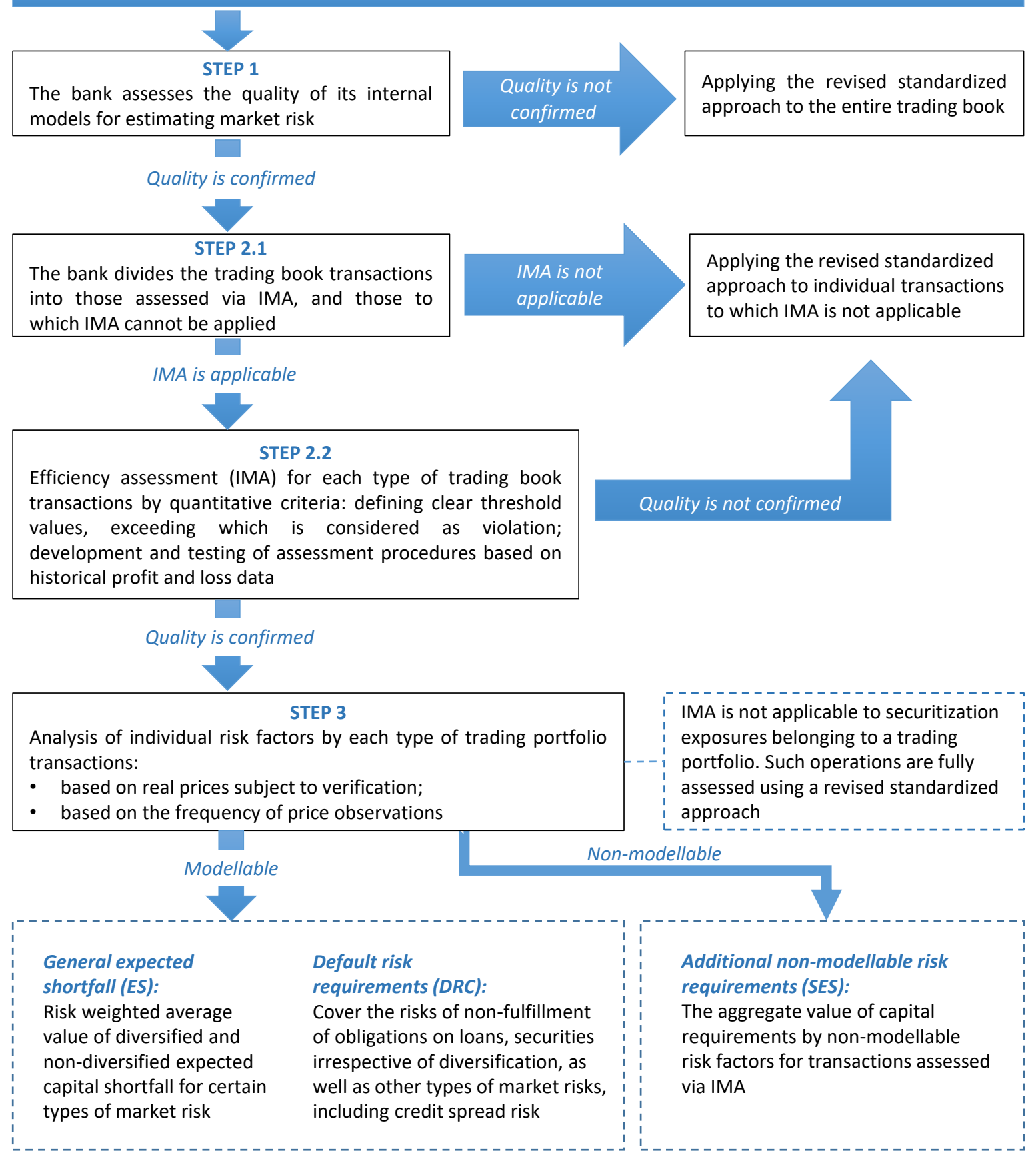

Figure 2. Assessment of capital requirements using the internal models approach

Ukraine is in line with the BCBS provisions and provides the general principles, according to which the articles of the bank balance sheet should be distributed (Bank for International Settlements, 2017, June).

Thus, the trading book contains bank assets and liabilities that are held for the purpose of trading or hedging the risks of other items in the trading book. Accordingly, the bank book includes assets and liabilities not included in the trading book.

However, the definition of trading and bank book boundaries under Basel II contains certain categories of financial instruments that may be in the same book by their nature, however, they may, if sufficiently justified and approved by a supervi- 
sor, be assigned to another book. That is, there are no clear distinctions regarding the belonging to a particular book in this document for these categories of financial instruments.

The lack of further clarification should encourage banks to impose a distinction between trading and bank books through their own consistent and well-founded choice.

However, as practice shows, there are cases where certain categories of financial instruments may belong to both the trading book and the bank book. In such cases, it may be unclear how to lay out the priority.

Therefore, the BCBS amends this part of the standards of market risk calculation and specifies under what conditions capital investments in funds (for example, stock index funds) can be included in the trading book. These are:

- daily quotations available;

- the ability to track benchmarks without leverage;

- the absolute value of the differences in the tracking process, not related to fees and commissions, is less than $1 \%$ (Bank for International Settlements, 2018, March).

The definition of more clear criteria for the distribution between trade and bank books is also an innovation of the revised BCBS approaches to calculating market risk. In particular, in the revised SA, while maintaining the link between a trading book and types of financial instruments:

- a clearer and consistent separation of trading and bank books is carried out;

- the scope of applying capital requirements to cover market risk is shifted;

- opportunities for arbitration are reduced while, at the same time, providing for appropriate control instruments;

- the criteria for inclusion/exclusion of the tools in/from the trading book are determined (based on the substantiality of the existing restrictions on the ability to eliminate such instruments or to be reliably assessed on a daily basis) in order to implement identical approaches to the distribution of types of instruments between the two books.

Control over any deviations from the above distribution criteria and initiating changes to the procedure for assigning a financial instrument to a trading/bank book is the responsibility of the supervisor if he considers that the financial instrument's belonging to the relevant book is determined incorrectly by the bank.

The effect of arbitrage on capital is mitigated by imposing strict restrictions on the financial instrument transfer from one book to another and even if, as a result of such transfer (in certain admissible cases), capital requirements for this financial instrument are reduced, the difference in costs measured on the moment of such transfer is recognized as additional fixed capital requirements disclosed.

Requirements for transferring internal risks from a bank book to a trading book are clearly identified for credit risk, capital risk, and interest rate risk.

The transfer of internal risks from a trading book to a bank book within a revised standardized approach is not recognized.

Capital requirements to cover market risk are calculated for financial instruments that do not contain any restrictive terms for trading or for their full hedging, and meet the following characteristics:

- the financial instrument is held with the purpose of:

a) short-term resale;

b) making profit from changes in prices in the short run;

c) blocking in order to receive arbitration profits;

d) hedging the risks arising from the retention of financial instruments with the a), b) and c) characteristics; 
- any of the following financial instruments (FI) is considered to be held for at least one of the following purposes:

a) FI correlates with the trading portfolio;

b) FI is the article of trade between traders who implement a clearly defined strategy within the framework of a risk management system;

c) FI leads to an increase in the current value of a bank book due to a decrease in the value of shares or as a result of an increase in the credit spread over the issuer/group of issuers' debt. That is, the bank will have a net short position in the stock risk or credit risk of the bank book;

d) FI arose as a result of underwriting liabilities.

- other financial instruments that do not satisfy the above characteristics, as well as:

a) non-listing shares;

b) warehousing securitization instruments;

c) real estate;

d) retail loans, loans for medium and small businesses (SMEs);

e) investments of the bank's share capital in funds, including hedge funds in which the bank cannot track the real changes in the value of the capital invested on a daily basis;

f) derivative financial instruments, according to which the base instrument meets the specified characteristics;

g) financial instruments, held by the bank in order to hedge positions at a certain risk and meet the specified characteristics, should be included in the bank book.

\subsection{Simplified (alternative) revised standardized method (R-SbM)}

The R-SbM method is a simplified version of the SA approach, providing a number of significant weaknesses in the application of the sensitivity-based method (SbM). These, in particular, are: cancellation of capital requirements for vega-risk and curvature; simplifying the basis risk calculation (as a delta risk factor when calculating the general interest rate risk (GIRR)); reducing the detail level of risk factors and correlation scenarios in related calculations. The remaining components of the SA approach for the R-SbM method do not change.

Simultaneous use of R-SbM, SbM and IMA methods by the bank for different types of financial instruments is not allowed.

The aim of the revision is to provide a transparent, consistent and comparable benchmark for banks of different jurisdictions and a market-risk standard that can be applied by banks in the event they refuse to use the Internal Models Approach (IMA).

At the same time, the Basel Committee on Banking Supervision recognizes the complexity of the SA and IMA approaches, even with the use of the simplified R-SbM method by banks insignificant in size or having negligible market risks or concentration of trading operations. This is because even this method differs significantly from the widely used standardized approach, according to Basel II. Therefore, the choice to implement revised SA and IMA approaches, even if the R-SbM method is used, will place Ukrainian banks at significant difficulties and costs that are inadequate to the significance of the risks in their trading books.

Instead, as part of harmonizing prudential standards in all jurisdictions and avoiding the need to develop their own simplifications for a revised standardized SbM approach, the BCBS allow for optional application of such approaches in all jurisdictions of countries (both BCBS members and non-members) in the revised format. The Committee also considers it possible to retain Basel II standardized approach to calculate market risk (Bank for International Settlements, n. d.; Bank for International Settlements, 2017, June).

At the same time, the BCBS allows the banks to maintain the use of Basel II's standardized approach as an alternative, subject to a high-level 
re-calibration, in order to ensure sufficient conservatism and be an improved alternative.

In particular, the proposed method for recalibrating the Basel II standardized approach involves applying the multiplier to capital requirements for each component of the standardized approach to market risk calculation according to Basel II (Bank for International Settlements, 2018, March).

According to this approach, the recalibrated capital requirements for market risk coverage will correspond to the sum of the following components:

$$
\begin{aligned}
& M R=I R R \cdot M I R R+E R \cdot M E R+ \\
& +F E R \cdot M F E R+C R \cdot M C R,
\end{aligned}
$$

where $M R$ - the amount of general requirements for covering market risk; IRR - requirements for the interest rate risk coverage under Basel II: Section VI (C), subsection 1 "Interest rate risk" and additional requirements for covering the risks of options for debt instruments (except delta risk) according to Basel II: Section VI (C), subsection 5 "Treatment of options"; MIRR - the range of coefficients for interest rate risk [1,50-2,0]; $E R$ - Basel II equity coverage requirements: Section VI (C), subsection 2 "Equity risk" and additional requirements for covering options for capital instruments (except for delta risk) under Basel II: Section VI (C), subsection 5 "Treatment of options"; MER - the range of coefficients for equity risk $[3,00-3,50]$, $F E R$ - requirements for foreign exchange risk coverage according to Basel II: Section VI (C), subsection 3 "Foreign exchange risk" and additional requirements for the coverage of options for foreign currency instruments (except for delta risk) according to Basel II: (Section VI (C), subsection 5 "Treatment of options"; MFER - the range of coefficients for foreign exchange risk [1,50-2,50]; $C R$ - commodity risk requirements according to Basel II: Section VI (C), subsection 4 "Commodity risk" and additional requirements for the coverage of options for commodity instruments (except for delta risk) under Basel II: (Section VI (C), subsection 5 "Treatment of options"; $M C R$ - the range of coefficients for commodity risk $[1,25-1,50]$.

Calibration should provide banks with more conservative approaches to market risk assessment compared to Basel II standardized approach. The BCBS does not specify restrictions on banks that may use such an approach (additionally, such an approach cannot be acceptable for global systemically important banks using internal models to evaluate certain types of financial instruments of a trading book or hold correlation trading portfolios).

The resulting capital requirement for market risk coverage should be translated into the risk-weighted assets equivalent multiplied by 10 (since the standard value is $\mathrm{N} 2 \geq 10 \%$ ).

\section{DISCUSSION AND CONCLUSION}

Thus, given the results of assessing the updated BCBS approaches to the market risk calculation, one can conclude that an optimal approach in terms of its implementation in Ukrainian banking practice (the capital adequacy ratio of banks (N2)) can be calculated in one of two scenarios by using: 1) a simplified version of the sensitivity based method (R-SbM); or 2) a re-calibrated version of the Basel II standardized approach.

With that, the recalibrated version of Basel II standardized approach is more acceptable for use by banks, since it is most relevant to the volume and complexity of transactions conducted by Ukrainian banks.

Given the current challenges facing the Ukrainian banking system (in particular, the need to increase capitalization, search for resources for development, etc.) and caused by limited opportunities due to the still significant share of non-working assets in the banks' balance sheets, improving the formula to calculate the norm (H2) by introducing qualitative and sensitive risk-based approaches, in particular to assessing market risk, will reduce the impact of destabilizing processes on banks as a result of market risk adoption and bring regulatory convergence requirements in Ukraine and the best international banking practices together. 
For this purpose, developing the BCBS-based criteria for the delineation of transactions carried out by banks between trading and bank books, should be an important prerequisite for implementing the chosen approach.

\section{REFERENCES}

1. Bank for International Settlements. (n. d.). Basel II: International Convergence of Capital Measurement and Capital Standards: A Revised Framework. November 2005. Retrieved from http://www.bis.org/

2. Alekserov, F. T., Andriievska, I. K., Penikas, H. I., \& Solodkov, V. M. (2010). Аналіз математичних моделей Базель II [Analiz matematychnykh modelei Basel II]. Moscow: Fizmatlit.

3. Altman, E. (2008). Managing Credit Risk (2nd ed) (450 p.). NJ: John Wiley and Sons.

4. Bank for International Settlements. (2011). Revisions to the Basel II market risk framework. Retrieved from http://www.bis.org/publ/ bcbs193.htm

5. Bank for International Settlements. (2016). Minimum capital requirements for market risk. Retrieved from http://www.bis. org/bcbs/publ/d352.htm

6. Bank for International Settlements. (2016, January). Standards Minimum capital requirements for market risk. Retrieved from http:// www.bis.org/

7. Bank for International Settlements. (2017, June). Consultative Document Simplified alternative to the standardized approach to market risk capital requirements. Retrieved from http://www.bis. org/

8. Bank for International Settlements. (2018, March). Consultative Document Revisions to the minimum capital requirements for market risk. Retrieved from http:// www.bis.org/

9. Basel Committee on Banking Supervision (n. d.). Minimum capital requirements for market risk. Retrieved from https://www. bis.org/bcbs/publ/d352.pdf
10. Basel Committee on Banking Supervision. (2005). Trading book survey: a summary of responses. Retrieved from www.bis.org/publ/ bcbs112.htm

11. Chornous, G., \& Ursulenko, G. (2013). Risk management in banks: new approaches to risk assessment and information support. Ekonomika, 92(1), 120132. Retrieved from http://www. zurnalai.vu.lt/ekonomika/article/ view/1131/599

12. Jorion, P. (1994). Value at Risk: The New Benchmark for Controlling Risk. Chicago-London.

13. Jorion, P. (1997). Value-at-Risk the new benchmark for controlling market risk. New York, USA: McGrawHill.

14. Kyung-Chun Mun. (2016, August). Hedging bank market risk with futures and forwards. The Quarterly Review of Economics and Finance, 61, 112-125. https:// doi.org/10.1016/j.qref.2015.11.004

15. Lobanov, O. (2017). Спрощений стандартизований підхід до оиінки ринкового ризику [Sproshchenyi standartyzovanyi pidkhid do otsinky rynkovoho ryzyku]. NDU Vyshcha shkola ekonomiky. Retrieved from http:// qps.ru/aDOuI

16. McKinsey\&Company. (2012, May). Managing market risk: Today and tomorrow (McKinsey Working Papers on Risk, No. 32). Retrieved from https://www. mckinsey.com/ /media/mckinsey/dotcom/client_service/Risk/ Working\%20papers/Working_Papers_on_Risk_32.ashx

17. Milanova, E. (2010). Market risk management in banks - models for analysis and assessment. FACTA UNIVERSITATIS Series: Economics and Organization, 7(4), 395-410. Retrieved from http:// facta.junis.ni.ac.rs/eao/eao201004/ eao201004-04.pdf
18. Ministry of Justice of the Russian Federation. (n. d.). Про порядок розрахунку кредитними установами величини ринкового ризику [Pro poriadok rozrakhunku kredytnymy ustaovamy velychyny rynkovoho ryzyku: Polozhennia Banku Rosii vid 03.12.2015 No. 511-П]. Retrieved from https://minjust.consultant.ru/ documents/17407

19. Mirković, V., Dašić, B., \& Siljković, B. (2013). Market risk management in banks. Retrieved from https:// www.researchgate.net/publication/321749017_MARKET_RISK_ MANAGEMENT_IN_BANKS

20. Mohd Fahmee Ab-Hamid, Aisyah Abdul-Rahman, Mariani AbdulMajid, \& Hawati Janor. (2018). Market Risk and Efficiencies of the Malaysian Banking Industry: The Post-merger and Acquisition Examination. Jurnal Ekonomi Malaysia, 52(1), 1-12.

21. Muriithi, J. G., Muturi, W. M., \& Waweru, K. M. (2016). The Effect of Market Risk on Financial Performance of Commercial Banks in Kenya. Journal of Finance and Accounting, 4(4), 225233. https://doi.org/10.11648/j. jfa.20160404.18

22. National Bank of Ukraine (2012). Інструкція про порядок регулювання діяльності банків в Україні. Постанова Правління Національного банку України від 28.08.2001 № 368 [Instruktsiia pro poriadok rehuliuvannia diialnosti bankiv v Ukraini. Postanova Pravlinnia Natsionalnoho banku Ukrainy vid 28.08.2001 No. 368].

23. National Bank of Ukraine (n. d.). Про розмір регулятивного капіталу банку. Лист НБу від 14.10.2008 № 47-412/106113829 [Pro rozmir rehuliatyvnoho kapitalu banku. Lyst NBU vid 14.10.2008 No. 47-412/1061-13829]. Retrieved from http://search. ligazakon.ua/1_doc2.nsf/link1/ LB08325.html 
24. NBU (n. d.). Методика розрахунку економічних нормативів регулювання діяльності банків в Україні. Постанова Правління Національного банку України від 2 червня 2009 року № 315 [Metodyka rozrakhunku ekonomichnykh normatuviv rehuliuvannia diialnosti bankiv $v$ Ukraini. Postanova Pravlinnia Natsionalnoho banku Ukrainy vid 2 chervnia 2009 roku No. 315]. Retrieved from https:// bank.gov.ua/document/

download? docId $=28624809$

25. Stezhkin, A. A., \& Malykh, N. O. (2013). Про підходи до оцінки ринкового ризику на основі Базеля III [Pro pidkhodu do otsinky rynkovoho ryzyku na osnovi Bazelia III]. Hroshi ta kredyt, 5, 21-24.

26. Trenca, I. (2009). The use in banks of value at risk method in market risk management. Retrieved from http://anale.feaa.uaic.ro/anale/ resurse/ 16_F12_Trenca.pdf

27. Положення про організацію системи управління ризиками в банках України та банківських групах [Polozhennia pro orhanizatsiiu systemy upravlinnia ryzykamy $v$ bankakh Ukrainy ta bankivskykh hrupakh: Postanova Pravlinnia Natsionalnoho banky Ukrainy vid 11.06.2018 No. 64]. Retrieved from http://zakon.rada. gov.ua/laws/show/v0064500-18 